\title{
ANALISIS HUBUNGAN PANJANG, BERAT DAN FAKTOR KONDISI IKAN TEMPAKUL (Periopthalmus barbarus) DI KAWASAN KONSERVASI MANGROVE DAN BEKANTAN (KKMB) KOTA TARAKAN
}

\section{ANALYSIS OF RELATIONSHIP LENGTH, WEIGHT AND CONDITION FACTORS TEMPAKUL FISH (Periophthalmus barbarus) IN THE MANGROVE AND BEKANTAN CONSERVATION AREA (KKMB) TARAKAN CITY}

\author{
Gazali Salim $^{1}$,Muhammad Firdaus ${ }^{1}$, Heriyana ${ }^{2}$ \\ ${ }^{1}$ Dosen, Fakultas Perikanan dan IImu Kelautan Universitas Borneo Tarakan \\ ${ }^{2}$ Mahasiswa Fakultas Perikanan dan IImu Kelautan, Universitas Borneo Tarakan \\ ‘Email : nenojali@gmail.com
}

\begin{abstract}
Conservation Mangrove and Bekantan Bakantan Mangrove conservation territory in Tarakan East Borneo built as located bakantan conservation and mangrove Education. For more manage grown as tourism destination. Purpose of this research know it analysist relationship between length and weight, and than conditions index of tempakul fishes (Periopthalmus barbarus) at Conservation mangrove and bekantan in Tarakan City. Researched as long as three months, on September to Desember 2018. This research used descriftif method from research founded tempakul tempakul fishes male and female. Negative allometric performel in factor of condition of tempakul fishes it's about 0,01-0,49 it showed that bodies of the fishes wash very slim
\end{abstract}

Keyword: Tarakan City, tempakul, relationship between lenght and weight, condition factor

\begin{abstract}
ABSTRAK
Kawasan konservasi Mangrove dan Bekantan Kota Tarakan, Kalimantan Utara, dibangun sebagai daerah konservasi bagi biota di mangrove dan biota bekantan,untuk dijadikan sebagai salah satu destinasi wisata dan pendidikan terutama dalam bidang penelitian. Tujuan penelitian ini mengetahui hubungan analisis antara panjang dan berat, dan dari indeks kondisi ikan tempakul (Periopthalmus barbarus) di Konservasi mangrove dan bekantan di Kota Tarakan. Penelitian di lakukan selama tiga bulan, pada bulan September hingga Desember 2018. Penelitian ini menggunakan metode descriftif dari penelitian tempakul ikan jantan dan betina. Hasil penelitian berdasarkan hubungan panjang berat didapatkan sifat pertumbuhan tempakul ikan jantan dan ikan betina bersifat alometrik negatif dan faktor kondisi ikan tempakul sekitar 0,01-0,49 itu menunjukkan bahwa tubuh ikan tempakul adalah sangat kurus.
\end{abstract}

Kata kunci: Kota Tarakan, Tempakul, sifat pertumbuhan, faktor kondisi

\section{PENDAHULUAN}

Tarakan merupakan kota terbesar di Provinsi Kalimantan Utara (Kaltara), Kota ini terpisah dari daratan Kalimantan dan berada pada sebuah pulau kecil. Kota
Tarakan juga sangat dekat dengan perbatasan antara Indonesia dan Malaysia. Luas Kota Tarakan adalah $250,80 \mathrm{~km}^{2}$ dengan populasi penduduk yang mencapai 239,787 jiwa. Kota Tarakan memiliki Kawasan hutan mangrove yang berada di 
J1. Gajah Mada. (Badan Pengelolaan Lingkunagan Hidup, 2010). Hutan mangrove merupakan komunitas pantai tropis yang didominasi oleh beberapa jenis pohon yang mampu tumbuh dan berkembang pada daerah pasang surut pantai berlumpur (Nybakken, 1988). Hutan mangrove umumnya tumbuh didaerah pada daerah intertidal dengan genangan air secara berkala dan menerima pasokan air tawar yang cukup. Seperti halnya yang berada di kawasan konservasi mangrove Kota Tarakan.

Kawasan Konservasi Mangrove dan Bekantan (KKMB) Kota Tarakan adalah salah satu destinasi wisata edukasi yang terletak di tengah Kota Tarakan di KKMB dan juga tempat bagi beragam jenis tumbuhan mangrove terutama bagi spesies hewan. Pada ekosistem mangrove ikan tempakul (Periopthalmus barbarous) merupakan konsumen tingkat pertama maupun tingkat kedua dalam rantai makanan. Menurut Al-Behbehani dan Ebrahim (2010) ikan tempakul mampu bertahan didaerah pasang surut karena memiliki kemampuan bernapas melalui kulit tubuhnya dan lapisan selaput lendir dimulut serta kerongkongannya.

Ekosistem mangrove memiliki produktivitas yang tinggi untuk mendukung keberadaan ikan. Ikan merupakan organisme yang menggunakan ekosistem mangrove untuk kelangsungan hidupnya. Nelayan dan masyarakat setempat berangapan ikan tempakul selama ini buakanlah tergolong kelompok ekonomis penting, menyebabkan nelayan dan pelaku budidaya belum menjadikan ikan tempakul sebagai target dalam usaha penangkapan dan budidaya.

Permasalahan yang mendasar mengenai potensi ikan tempakul yang berada di KKMB Kota Tarakan belum tersedianya data ilmiah dan pola pemanfaatan ikan tempakul yang belum ada atau belum optimal oleh masyarakat sekitar kawasan KKMB tersebut. Hal tersebut berbeda dengan fauna akuatik lainnya di kawasan tersebut, seperti udang dan kepiting.
Berdasarkan hasil wawancara dengan masyarakat sekitar kawasan KKMB dan petugas KKMB bahwa ikan tempakul pada tahun 2001 pernah menjadi komoditi yang di ekspor oleh perusahaan PT. Mustika Minanusa Aurora dan hanya berlangsung selama 1 tahun saja.

Hingga saat ini potensi ikan tempakul belum ada pola pemanfaatannya dan data informasi ilmiahnya masih kurang tersedia. Penelitian tentang ikan tempakul di kawasan KKMB telah dilakukan oleh Susiyanti (2018) tentang sifat pertumbuhannya dan dilakukan oleh Latif A.A (2016) tentang Studi Populasi dan Morfometrik Ikan Gelodok (data morfometrik - meristik, hubungan panjang berat dan faktor kondisi). Hal tersebut menjadi dasar pemikiran peneliti untuk melengkapi informasi ilmiah tentang ikan tempakul, yang diharapkan menjadi data ilmiah dalam pengolahan sumberdaya ikan tempakul secara lestari dan berkelanjutan di kawasan tersebut.

\section{METODE PENELITIAN}

Metode yang digunakan dalam penelitian ini adalah deskriptif. Data yang diambil adalah data ikan tempakul di Kawasan Konservasi Mangrove dan Bekantan.

Penelitian ini dilaksanakan pada bulan September sampai Desember 2018 di KKMB Kota Tarakan Kalimantan Utara. Pengukuran dilakukan di Laboratorium Kualitas Air Fakultas Perikanan dan Ilmu Kelautan Universitas Borneo Tarakan.

Alat-alat yang digunakan selama penelitian yaitu GPS, Kamera, Timbangan dijital, Meteran, Pole bag (serok tongkat), Nampan, Tissue, Tali Rapia, Alat Tulis, Alumunium foil, dan Penggaris, Plastik. Bahan yang digunakan yaitu Sampel Ikan Tempakul.

\section{Penentuan Lokasi}

Penentuan lokasi dilakukan dengan menggunakan metode purposive sampling. Pemilihan lokasi tersebut Plot pengamatan yang dipilih berada dipeluasan 12 ha. 


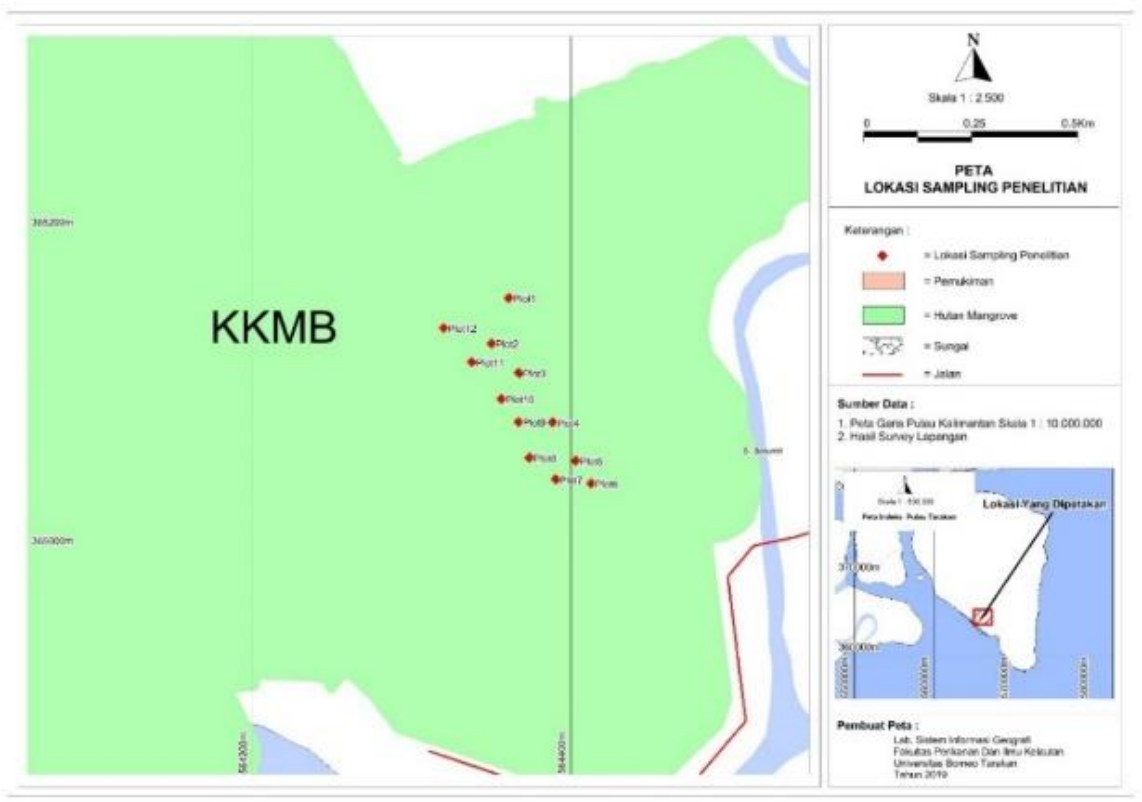

Gambar 1. Peta Lokasi Penelitian

\section{Desain Pengambilan Sampel}

Pengambilan sampel dilakukan di Kawasan Konservasi Mangrove dan Bekantan (KKMB) di daerah perluasan 12 ha, dengan masing-masing sebanyak 12 plot/transek 10 x $10 \mathrm{M}^{2}$ dan diberi jarak setiap plot/translet.

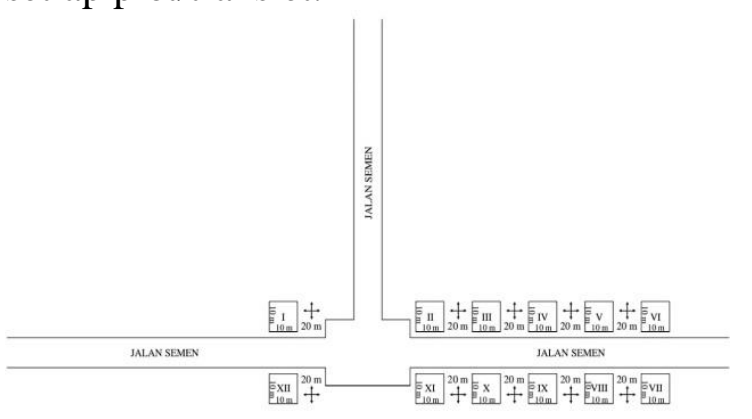

Gambar 2. Desain Pengambilan sampel

\section{Pengambilan Data Ikan Tempakul}

Pengamatan yang dilakukan pada ikan tempakul diamati pada saat air surut dan air pasang, pengambilan sampel dilakukan sebanyak 1 plot setiap minggu. Pengambilan sampel menggunakan pole bag (serok tongkat) dimana sampel tersebut berukuran kecil dan berukuran besar jika ada ikan tempakul didalam genangan air maka diarahkan ke ikan tempakul (Metode modifikasi). Setelah sampel didapatkan dimasukkan ke dalam plastik dan disimpan dilemari pendingin (freezer) dan kemudian dilanjut dengan pengukuran di Laboratorium.

\section{Analisis Data}

\section{Hubungan Panjang Berat}

Hubungan panjang atau length (L) dan berat atau weigth (W) dalam menggambarkan sifat pertumbuhan ikan tempakul dalam kajian populasi ikan tersebut, dihitung menggunakan pola kubik yang kemudian ditransformasikan ke dalam bentuk logaritma menjadi persamaan linier (Effendie,). Formulasi pola kubik tersebut sebagai berikut:

Persamaan regresi sederhana: $=a+b^{x}$, menjadi, Hubungan L - W (pola kubik):

$\mathbf{W}=\mathbf{a} \mathbf{L}^{\mathbf{b}}$, menjadi

$$
\ln W=\ln a+b \ln L
$$

Dimana:

$\mathrm{W}=$ Berat (gram)

$\mathrm{L} \quad=$ Panjang $(\mathrm{cm})$

$\mathrm{a}$ dan $\mathrm{b}=$ Konstanta (intercept and slope)

Nilai $b$ pada hubungan panjang dan berat dalam sifat pertumbuhan ikan mengekspersikan bentuk tubuh suatu ikan. Bentuk tubuh ikan tersebut dapat berbentuk: kurus/ramping, ideal (isometrik), atau gemuk/montok. Nilai $b=3$ 
berarti pertumbuhannya isometrik yaitu pertumbuhan panjang akan selalu di ikuti dengan pertambahan berat (pertumbuhan seimbang).

Jika nilai $b>3$ atau $b<3$ berarti nilai $b \neq 3$ berarti pertumbuhannya allometrik yaitu pertumbuhan panjang tidak selalu diikuti dengan pertumbuhan berat (pertumbuhan tidak seimbang). Sifat pertumbuhan yang tidak seimbang ini dapat bernilai al lometrik negatif $(b<3)$ yang berarti bentuk tubuh ramping/kurus dan bernilai allometrik positif $(b>3)$ yang berarti bentuk tubuh ikan montok/gemuk (Effendie, 2002).

\section{Faktor Kondisi}

Dalam mengekspresikan bentuk tubuh ikan secara detail menggunakan pendekatan nilai faktor kondisi Lagler's (Effendie, 2002). Sifat pertumbuhan isometrik adalah nilai $\mathrm{K}$ dalam sistem metrik dengan nilai $10^{5}$ sedemikian rupa hingga nilai $\mathrm{K}$ mendekati 1, yaitu:

dimana;

$$
K_{(T I)}=10^{5} * W / L^{3}
$$

$K_{(T I)}=$ faktor kondisi isometrik

$W \quad=$ berat sampel aktual (gram)

$L \quad=$ panjang sampel actual $(\mathrm{cm})$

Nilai faktor kondisi Le Cren's (Raeisi, et.al., 2011) untuk sifat pertumbuhan allometrik yaitu:

dimana;

$$
K n=W / \hat{W}
$$

$K n \quad=$ faktor kondisi relatif

$W \quad=$ berat sampel aktual (gram)

$\hat{W} \quad=$ berat sampel dugaan $(\mathrm{cm})$, berat ikan dugaan dari hasil $\log$ $W=a+b * \log L$

Nilai faktor kondisi modifikasi dari Fulton's (Abobi and Ekau, 2013), yaitu:

dimana;

$$
\mathrm{K}=\mathrm{W} * 100 / \mathrm{L}^{\mathrm{b}}
$$

$K \quad=$ faktor kondisi

$W \quad=$ berat sampel mutlak (gram)

$L \quad=$ panjang sampel mutlak $(\mathrm{cm})$

$b=$ koefisien slope persamaan eksponensial

\section{HASIL DAN PEMBAHASAN}

Gambaran Umum Lokasi Penelitian

Lokasi penelitian di Kawasan Konservasi Mangrove dan Bekantan (KKMB) Kota Tarakan.

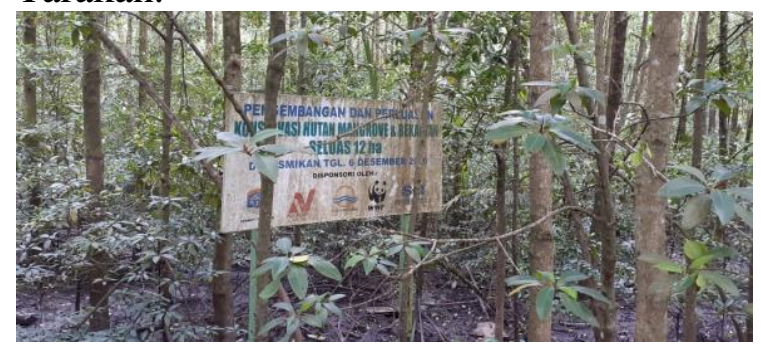

Gambar 3. Lokasi Penelitian Perlusan 12ha

Kawasan Konservasi Mangrove dan Bekantan berdasarkan pengelolaannya dibagi menjadi kawasan hutan seluas 9 hektar dengan jenis mangrove asli dan kawasan perluasan seluas 12 hektar. KKMB yang ditujukan untuk melestarikan ekosistem mangrove dan satwa liar dalam perkembangannya diarahkan sebagai daerah tujuan ekowisata alternatif (Dinas Lingkungan Hidup dan SDA Kota Tarakan, 2007; Yusuf, 2008). Ekowisata memberikan kesempatan bagi para wisatawan untuk menikmati keindahan alam dan budaya lokal serta mempelajari tentang pentingnya berbagai ragam mahluk hidup yang ada di dalamnya. Selain itu, kegiatan ekowisata juga dapat meningkatkan pendapatan untuk pelestarian alam serta menghasilkan keuntungan ekonomi bagi kehidupan masyarakat di sekitarnya (Subadra, 2008).

\section{Hasil Penelitian}

Hasil penelitian yang didapatkan didaerah perluasan 12 ha KKMB Kota Tarakan ditemukan jumlah sampel ikan tempakul (Periopthalmus barbarus) sebanyak 194 ekor. Terdiri dari 102 ekor jantan dan 92 ekor betina. Ikan tempakul yang tertangkap selama penelitian dapat dilihat pada (Gambar 8). 


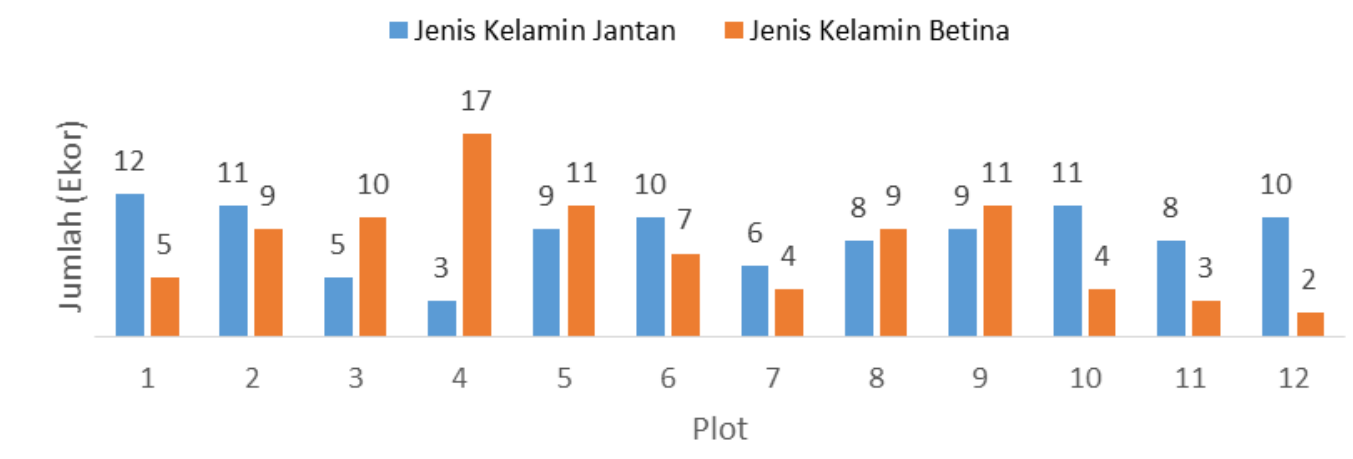

Gambar 4. Jumlah ikan tempakul yang tertangkap per plot

Berdasarkan gambar diatas dapat dilihat nilai tertinggi ikan tempakul jantan terdapat pada plot 1 yaitu 12 ekor sedangkan ikan tempakul betina pada plot 4 sebanyak 17 ekor. Jumlah ikan tempakul jantan yang paling rendah terdapat pada plot 4 yaitu 3 ekor, sedangkan pada ikan tempakaul betina terdapat pada plot 12 yaitu 2 ekor dan pada plot 11 yaitu 3 ekor. Hal ini disebabkan ikan-ikan yang sangat mudah belum mempunyai kemampuan hidup yang baik dan tempat hidupnya dan adanya kalah bersaing mendapatkan makanan dengan ikan yang lebih tua (Pandu, 2011), dan perbedaan faktor kondisi ikan diduga karena tidak agresi atau dalam keadaan diam.

Mengingat ikan tempakul ini takut dengan adanya manusia, selain itu faktor makanan dan vegetasi mangrove sehingga kepadatan ikan tempakul menjadi rendah atau tidak merata. Kusuma, (1995) mengatakan bahwa keberadaan hutan mangrove dan pantai mempunyai fungsi ekologis yaitu sebgai feeling ground, tempat pemijahan dan nurse ground berbagai jenis ikan dan biota laut lainnya. Pada plot 1 jumlah ikan tempakul jantan banyak ditemukan pada saat pengambilan sampel, kondisi lingkungan sekitar perluasan KKMB Kota Tarakan diduga dipengaruhi faktor adanya jumlah vegetasi mangrove belum padat.

\section{Pertumbuhan Panjang dan Berat Ikan Tempakul}

Hasil pengukuran panjang dan berat ikan tempakul bertujuan untuk mengetahui seberapa besar hubungan atau korelasi antara panjang dan berat ikan tempakul dan beberapa faktor panjang pengaruhi berat. Selain itu dari hubungan panjang dan berat ikan dapat juga diketahui pertumbuhan ikan mengenai adanya keseimbangan yang terjadi antara panjang dan berat ikan tempakul.

Menurut Effendie (2002) terdapat dua pola pertumbuhan yaitu pertumbuhan isometrik dan alometrik. Pertumbuhan isometrik dimaksudkan sebagai perubahan terus menerus secara proporsional antara panjang atau dengan berat dalam tubuh ikan, sedangkan pertumbuhan alometrik dijelaskan bahwa sebagai perubahan antara ukuran dan berat yang tidak proporsional. 

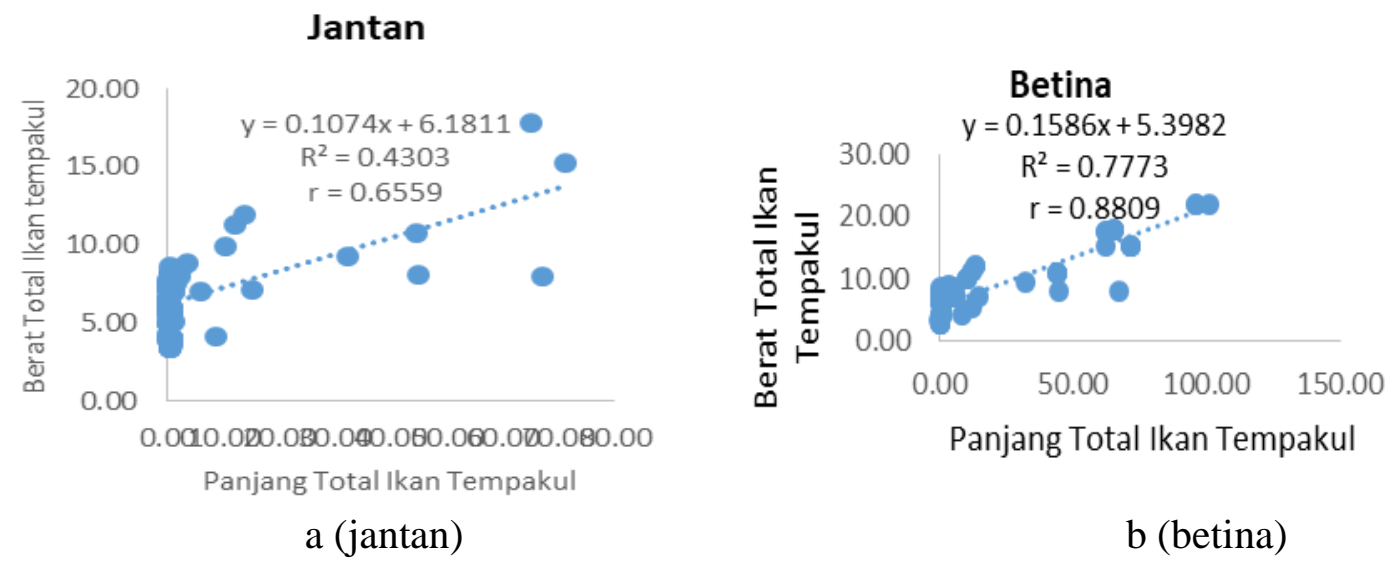

Gambar 5. Grafik hubungan panjang-berat tempakul jenis kelamin a (Jantan) dan b (Betina)

Berdasarkan hasil analisis hubungan panjang-berat ikan tempakul (Periopthalmus barbarus) jantan menunjukkan nilai kofisien determinasi $\left(\mathrm{R}^{2}\right)$ berkisar 0.4303 dan kofisien korelasi (r) berkisar 0.6559 oleh karena itu dengan persamaan hubungan panjang dan berat ikan tempakul secara umum memiliki korelasi yang kuat. Nilai kofisien korelasi menunjukkan bahwa setiap penambahan bobot ikan akan diiringi dengan penambahan panjang setiap waktu pengamatan (Hartonoll, 1983). Berdasarkan hasil analisi hubungan panjang-berat ikan tempakul (Periopthalmus barbarus) jantan didapatkan model $\mathrm{y}=0.1074 \mathrm{x}+6.1811$ dimana nilai $\mathrm{b}$ sebesar 0.1074 hasil yang didapatkan seperti terlihat pada (Gambar 8) nilai b < 3 yang memiliki arti bahwa pola pertumbuhannya adalah allometrik negatif, sehingga ikan tempakul jantan pertumbuhan panjangnya lebih cepat dibandingkan dengan pertambahan bobot tubuh ikan (Effendie, 2002). Hasil penelitian ini juga diperkuat oleh penelitian yang dilakukan oleh Effendie dan Sjafei (1973) di daerah Tangerang yang menyatakan bahwa ikan tempakul memiliki pola pertumbuhan allometrik.

Berdasarkan hasil analisis terhadap P.barbarus jantan nilai kofisien diterminasi $\left(\mathrm{R}^{2}\right)$ berkisar 0,4303 dan kofisien korelasi (r) berkisar 0,6559 dan hasil analisis hubungan panjang-berat ikan tempakul (Periopthalmus barbarus) betina menunjukkan nilai kofisien diterminasi $\left(\mathrm{R}^{2}\right)$ berkisar 0,7760 dan kofisien korelasi (r) berkisar 0,8809. Oleh karena itu dengan persamaan hubungan panjang dan berat ikan tempakul secara umum memiliki korelasi yang erat. Nilai kofisien korelasi menunjukkan bahwa setiap penambahan bobot ikan akan diiringi dengan penambahan panjang setiap waktu pengamatan (Hartonoll, 1983).

Berdasarkan hasil analisi hubungan panjang-berat ikan tempakul (Periopthalmus barbarus) betina didapatkan model $\mathrm{y}=5,3445 \mathrm{x}+0.1592$ dimana nilai b sebesar 0,1586 hasil yang didapatkan seperti terlihat pada (Gambar 5) nilai $b<3$ yang memiliki arti bahwa pola pertumbuhannya adalah allometrik negatif, sehingga ikan tempakul jantan pertumbuhan panjang ikan lebih cepat dibandingkan dengan pertambahan bobot tubuh ikan (Effendie, 2002). Hasil penelitian ini juga diperkuat oleh penelitian yang dilakukan oleh Effendie dan Sjafei (1973) di daerah Tangerang yang menyatakan bahwa ikan tempakul memiliki pola pertumbuhan allometrik.

Berdasarkan hasil analisis terhadap ikan tempakul (Periopthalmus barbarus) betina menunjukkan nilai kofisien diterminasi $\left(\mathrm{R}^{2}\right)$ berkisar 0,7760 dan kofisien korelasi (r) berkisar 0,8809. Hal ini sesui dengan penelitian yang dilakukan oleh Djumanto et al., (2012) bahwa kofisien korelasi 
antara panjang total dan bobot pada ikan betina $(r=0,8809)$ sangat erat dan kuat. Tingginya nilai kofisien korelasi yang diperoleh dari hubungan panjang-bobot menyatakan bahwa terdapat hubungan yang sangat erat antara panjang tubuh total dan berat tubuh total. Menurut Walpole (1992), jika nilai (r) mendekati 1 maka terdapat hubungan yang kuat antara kedua variable.

Pola pertumbuhan allometrik negatif juga telah dilaporkan pada beberapa spesies ikan dari perairan Aceh misalnya, ikan depik Rasbora tawarensis dan ikan kawan Poropuntius tawarensis (Muchlisin et al., 2010). Pola pertumbuhan ikan dipengaruhi oleh beberapa faktor antara lain ketersediaan makanan dan kondisi perairan. Menurut Muchlisin et al., (2016) menjelaskan bahwa koefesiensi (b) dipengaruhi perilaku ikan, ikan perenang aktif menunjukkan bahwa nilai (b) lebih rendah dibandingkan dengan ikan perenang pasif, mungkin hal ini terkait dengan alokasi energi yang dikeluarkan untuk pergerakan dan pertumbuhannya.

Berdasarkan (Gambar 5) diatas antara ikan jantan dan betina, memiliki persamaan regresi $\mathrm{y}=6,1811+0,1074 \mathrm{x}$ dengan nilai determinan sebesar $43 \%$ dan nilai korelasi sebesar $65,59 \%$, sedangkan pada ikan betina setelah dianalisis didapatkan persamaan regresi yaitu $\mathrm{y}=5,3445+$ $0,1592 \mathrm{x}$ dengan nilai determinan sebesar $77,60 \%$ dan nilai korelasi sebesar $88 \%$. Ikan jantan menunjukkan nilai konstanta (Slope) sebesar 0,1074 dan ikan betina menunjukkan nilai konstanta (Slope) sebesar 0.1586. Menurut Effendie, (2002) $\mathrm{b}>3$ menunjukkan bahwa bersifat Allometrik positif sedangkan $\mathrm{b}<3$ menunjukkan bahwa sifat Allometrik negatif.

Hasil penelitian ikan tempakul berjenis kelamin jantan dan betina bersifat allometrik negatif. Hasil grafik hubungan panjang dan berat didapatkan $\mathrm{R}^{2}$ ikan tempakul jantan 0,4303 (43\%) dan nilai korelasi sebesar $65,59 \%$ sedangkan untuk ikan tempakul betina nilai $\mathrm{R}^{2}$ ikan tempakul betina adalah $77,60 \%$ dengan nilai korelasi sebesar $88 \%$, determinasi artinya adalah untuk melihat seberapa besar faktor yang mempengaruhi pertumbuhan ikan tempakul (Periopthalmus barbarus) sedangkan nilai korelasi artinya adalah untuk melihat hubungan keterkaitan antara panjang total dan berat total ikan tempakul. Hasil grafik hubungan panjang berat dari ikan tempakul baik jantan maupun betina, maka titik yang berada digaris maupun dibawah garis persamaan regresi. Sumbu $X$ merupakan log dari panjang sumbu $\mathrm{X}$ sebenarnya dimulai dari titik nol, karena data yang didapat memiliki kisaran 1,00-9,65 untuk ikan jantan 0,51-2,05 maka untuk memperjelas data, sumbu $\mathrm{X}$ tidak dimulai dari nol.

\section{Faktor Kondisi Ikan Tempakul (Periopthalmus barbarus)}

Faktor kondisi merupakan bagian pertumbuhan yang sangat penting dalam menganalisa populasi ikan dan dapat digunakan untuk mengetahi bentuk tubuh ikan (Lagler, 1962).

Tabel 1. Faktor kondisi ikan tempakul

\begin{tabular}{cccc}
\hline \multirow{2}{*}{ Spesies } & Persamaan Hubungan & \multicolumn{2}{c}{ Faktor Kondisi } \\
\cline { 3 - 4 } & Panjang Berat & Kisaran & Rata-rata \\
\hline \multirow{2}{*}{ Ikan Tempakul } & Jantan & $5,925 \pm 5,905$ & 0,73 \\
& Betina & $19,462 \pm 19,495$ & 2,89 \\
\hline
\end{tabular}


Hasil analisis faktor kondisi (FK) ikan tempakul di Kawasan Konservasi Mangrove dan Bekantan (KKMB) Kota Tarakan untuk ikan tempakul jantan berkisar antara $5,925 \pm 5,905$ dengan nilai rata-rata 0,73 untuk ikan tempakul betina berkisaran 19,462 \pm 19,495 dengan nilai rata-rata 2,89. Faktor kondisi tertinggi terdapat pada ikan tempakul betina. Hal ini didukung oleh pernyataan Masriwaty (2002), bahwa faktor kondisi dari suatu jenis ikan tidak tetap sifatnya. Apabila dalam suatu perairan terjadi perubahan yang mendadak terhadap kondisi ikan maka dapat mempengaruhi faktor kondisi ikan tersebut, bila kondisinya kurang baik mungkin disebabkan populasi ikan terlalu padat maka kemungkinana terjadi pengurangan populasi atau ketersediaan makanan di perairan cukup melimpah sehingga populasinya menyebar.

Nilai yang diperoleh dari jenis ikan tempakul jantan dan betina tersebut menunjukkan tubuh sangat pipih/kurus. Menurut Effendie (1997), apabila faktor kondisi berkisar 1-2 menunjukkan tubuh ikan pipih/kurus. Faktor kondisi dapat naik dan turun karena merupakan indikasi dari musim pemijahan bagi ikan, khususnya ikan ikan betina (Effendie 2002). Nilai faktor kondisi akan meningkat menjelang puncak pemijahan dan menurun setelah pemijahan juga ditemukan pada ikan Johnius belangerii (Rahardjo \& Simanjuntak 2008) dan Trachurus mediterraneus (Tzikas et al., 2007). Hal ini dikarenakan sumber energi utama digunakan untuk perkembangan gonad dan pemijahan (Lizama et al., 2002). Fariasi nilai faktor kondisi $(\mathrm{K})$ sangat ditentukan oleh makanan, umur, jenis kelamin dan tingkat kematangan gonad (Effendie 2002).

\section{Faktor Kondisi Ikan Tempakul Jantan}

Menurut Effendie dalam Salim, (2012) menunjukkan bahwa kisaran angka dari indeks kondisi berkisar antara $\leq 0,49$ sangat pipih/kurus, pipih/kurus kisaran antara 0,50-0,99, proporsional terdapat pada kisaran 1, gemuk/montok terdapat kisaran antara 1.01-1.49 dan sangat gemuk kisaran antara $\leq 1.50$.

Tabel 2. Persentase karakter Indeks Kondisi

\begin{tabular}{ccccc}
\hline Bentuk Tubuh & Kisaran Kn & $\sum$ Sampel & \multicolumn{2}{c}{ Persentase (\%) } \\
\hline sangat pipih/kurus & $0.01-0,49$ & 89 & $87.3 \%$ & \multirow{2}{*}{ (\%.2\% } \\
pipih/kurus & $0.50-0.99$ & 1 & $1.0 \%$ & \\
proporsional & 1 & 0 & $0.0 \%$ & \\
gemuk/montok & $1.01-1.49$ & 2 & $2.0 \%$ & $11.8 \%$ \\
sangat gemuk/montok & $\geq 1,50$ & 10 & $9.8 \%$ & \\
\hline
\end{tabular}

Menurut Salim (2013)

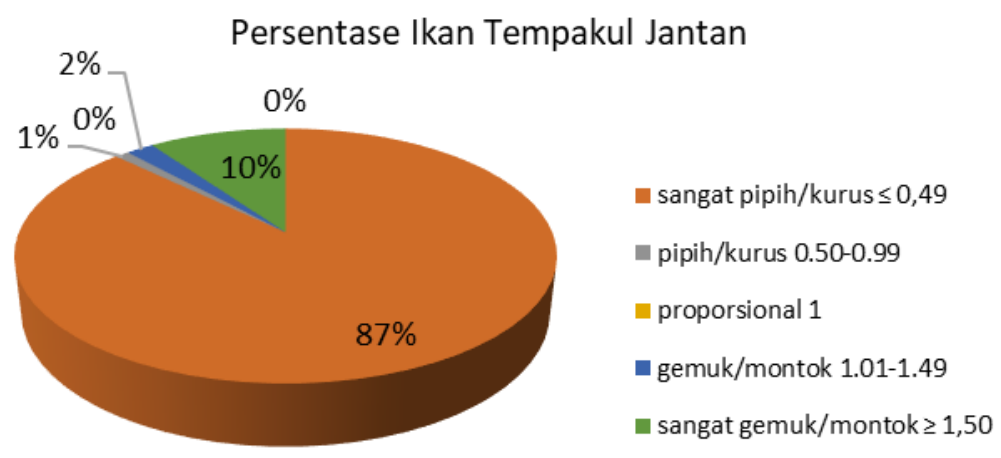

Gambar 6. Persentase indeks ikan tempakul jantan 
Persentase indeks kondisi ikan tempakul jantan dapat dilihat pada (Tabel 6) dan (Gambar 6), dimana menunjukkan bahwa persentase ikan tempakul jenis jantan didapatkan berkisar antara $87.3 \%$ dengan jumlah 89 sampel, dan memiliki bentuk tubuh sangat pipih/kurus yang dapat dilihat pada kolom kedua (Tabel 2). Terdapat sampel dengan persentase berkisar antara
$1,0 \%$ dengan bentuk tubuh pipih/kurus terdapat pada sampel 1. Terdapat sampel dengan persentase berkisar antara 2,0\% dengan bentuk tubuh gemuk/montok pada sampel 2 dan kolom ke 5 dengan bentuk tubuh sangat gemuk/montok terdapat sampel dengan persentase berkisar antara $9,8 \%$ dengan bentuk tubuh sangat gemuk/montok, dengan jumlah 11 ekor.

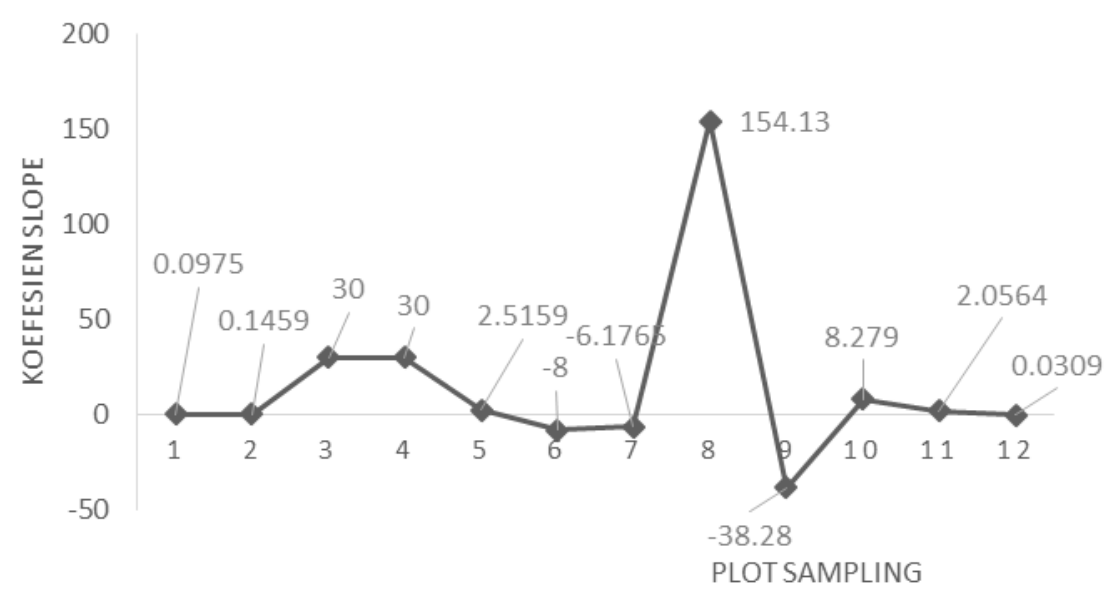

Gambar 7. Nilai b per plot ikan Jantan

Hasil pengklasifikasian pada (Gambar 8) jumlah ikan berbentuk sangat pipih/kurus $87 \%$ lebih banyak ditemukan pada ikan jantan 89 ekor, jumlah ikan berbentuk pipih $0 \%$ ditemukan pada ikan betina 1 ekor, jumlah ikan berbentuk gemuk/montok $2 \%$ ditemukan pada ikan betina 2 ekor dan jumlah ikan berbentuk sangat gemuk/montok $10 \%$ ditemukan pada ikan betina 10 ekor. Hal ini disebabkan ikan-ikan yang diduga masih muda belum mempunyai kemampuan hidup yang baik dan dapat diduga pula karena kalah bersaing mendapatkan makanan dengan ikan yang lebih tua (Pandu, 2011) dan diduga fakor lingkungan dapat mempengaruhi ekologis bentuk tubuh ikan.

\section{Faktor kondisi ikan Tempakul betina}

Menurut Effendie, (2002) menunjukkan bahwa kisaran angka dari indeks berkisar 0,01-0,49 sangat pipih/kurus, pipih/kurus kisaran 0,50-0,99, proporsional I, gemuk/montok 1,01-1,49 dan sangatt gemuk kisaran $\leq 1,50$.

Tabel 3. Persentase karakter indeks kondisi ikan tempakul betina

\begin{tabular}{lcccc}
\hline \multicolumn{1}{c}{ Bentuk Tubuh } & Kisaran Kn & Sampel & \multicolumn{2}{c}{ Persentase (\%) } \\
\hline sangat pipih/kurus & $0.01-0,49$ & 56 & $54.9 \%$ & \multirow{2}{*}{$57.8 \%$} \\
pipih/kurus & $0.50-0.99$ & 3 & $2.9 \%$ & \\
Proporsional & 1 & 0 & $0.0 \%$ & \\
gemuk/montok & $1.01-1.49$ & 4 & $3.9 \%$ & $32.4 \%$ \\
sangat gemuk/montok & $\geq 1,50$ & 29 & $28.4 \%$ & \\
\hline
\end{tabular}

Menurut Salim 2013 


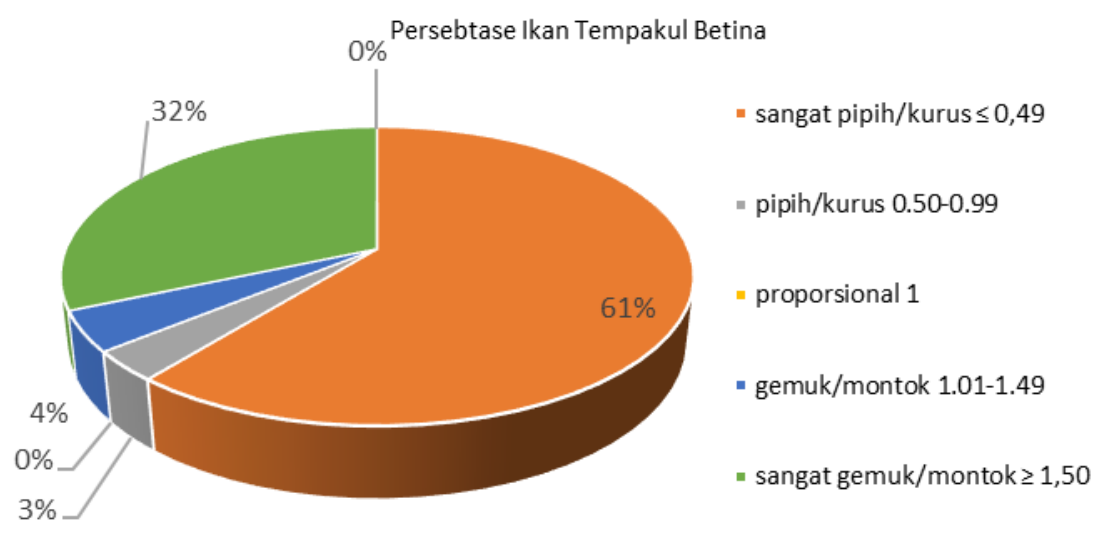

Gambar 8. Persentase indeks ikan tempakul betina

Pada tabel 3 menunjukkan faktor kondisi yang berkarakter sangat pipih/kurus berjumlah 56 ekor dengan presantase $54,9 \%$, yang berkarakter pipih/kurus berjumlah 3 ekor dengan presentase 2,9\%, berkarakter proporsional berjumlah 0 dengan presentase $0.0 \%$, berkarakter gemuk/montok berjumlah 4 ekor dengan presentase $3.9 \%$ dan yang berkarakter sangat gemuk montok berjumlah 29 ekor dengan presentase $28,4 \%$. Hasil analisis yang didapatkan berdasarkan kategori yang dikemukakan oleh Salim et al., (2012) yang dibagi menjadi 5 kategori bentuk tubuh ikan yaitu, sangat pipih, pipih, proposional, gemuk dan sangat gemuk.

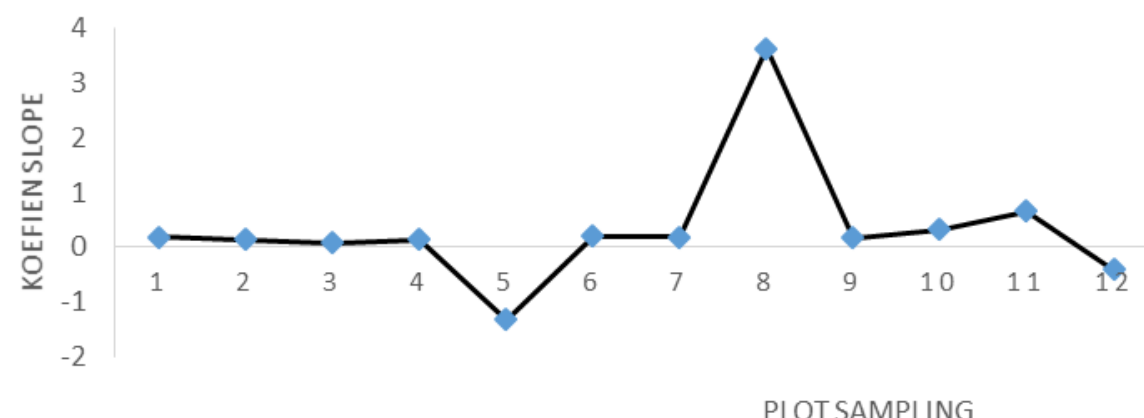

Gambar 9. Nilai b per plot ikan betina

Hasil pengklasifikasikan pada (Gambar 9) jumlah ikan berbentuk sangat pipi/kurus $61 \%$ lebih banyak ditemukan pada ikan betina 56 ekor, jumlah ikan berbentuk pipih $0 \%$ ditemukan pada ikan betina 3 ekor, jumlah ikan berbentuk gemuk/montok $4 \%$ ditemukan pada ikan betina 4 ekor dan jumlah ikan berbentuk sangat gemuk/montok 32\% ditemukan pada ikan betina 29 ekor. Hal ini disebabkan ikan-ikan yang sangat mudah belum mempunyai kemampuan hidup yang baik dan tempat hidupnya dan adanya kalah bersaing mendapatkan makanan dengan ikan yang lebih tua (Pandu, 2011), dan perbedaan faktor kondisi ikan diduga karena tidak agresifan atau dalam keadaan diam.

Pada dasarnya pertumbuhan allometrik bersifat sementara, misalnya karena perubahan yang berhubungan dengan kematangan gonad, sedangkan pertumbuhan isometrik merupakan perubahan secara terus menerus yang bersifat proporsional (Effendie, 2002). Perbedaan pertumbuhan ikan yang diekspresikan dari nilai b dapat disebabkan oleh beberapa faktor, seperti perbedaan umur, perkembangan gonad, jenis kelamin, kondisi habitat, kepenuhan 
lambung, faktor penyakit dan parasit (Effendie, 2002). Hasil dari penelitian pengambilan sampel ikan tempakul yang dilakukan di KKMB Kota Tarakan di area perluasan 12 hektar, jumlah sampel sebanyak 194 ekor ikan tempakul dan terbagi dari jantan dan betina, selanjutnya dilakukan perbandingan pada tahun 2016, 2018 dan 2019.

Tabel 4. Sifat Pertumbuhan Ikan Tempakul (Periopthalmus barbarus)

\begin{tabular}{|c|c|c|c|c|c|}
\hline No & $\begin{array}{c}\text { Jenis } \\
\text { Kelamin } \\
\text { Ikan } \\
\text { Tempakul }\end{array}$ & $\begin{array}{l}\text { Hasil Penelitian } \\
\text { Sifat Pertumbuhan } \\
\text { Persamaan Regresi }\end{array}$ & Penelitian & Tahun & Sifat Pertumbuhan \\
\hline 1 & $\begin{array}{l}\text { Jantan } \\
\text { Betina }\end{array}$ & $\begin{array}{l}\text { Allometri Negatif } \\
\text { Allometri Negatif }\end{array}$ & Adil Abdul Latif & 2016 & $\begin{array}{l}\text { Allometri Negatif } \\
\text { Allometri Negatif }\end{array}$ \\
\hline 2 & $\begin{array}{l}\text { Jantan } \\
\text { Betina }\end{array}$ & $\begin{array}{l}\text { Allometri Negatif } \\
\text { Allometri Negatif }\end{array}$ & Susianti & 2018 & $\begin{array}{l}\text { Allometri Negatif } \\
\text { Allometri Negatif }\end{array}$ \\
\hline 3 & $\begin{array}{l}\text { Jantan } \\
\text { Betina }\end{array}$ & $\begin{array}{l}\text { Allometri Negatif } \\
\text { Allometri Negatif }\end{array}$ & Heriyana & 2019 & $\begin{array}{l}\text { Allometri Negatif } \\
\text { Allometri Negatif }\end{array}$ \\
\hline
\end{tabular}

Penelitian yang dilakukan pada tahun 2016 didapatkan presentase panjang dan berat ikan tempakul jantan sebesar $98.4 \%$ dengan sifat pertumbuhan allometrik negatif. Sedangkan presentase panjang dan berat ikan tempakul betina sebesar $98.9 \%$ dengan sifat pertumbuhan allometrik negatif. Penelitian yang dilakukan pada tahun 2018 didapatkan pesentase panjang dan berat ikan temapakul betina sebesar $98.8 \%$ dengan sifat pertumbuhan allometrik negatif dan presentase panjang dan berat ikan tempakul jantan sebesar $79.8 \%$ dengan sifat pertumbuhan allometrik negatif. Sedangkan pada penelitian ini didapatkan presentase panjang dan berat ikan tempakul jantan $87.4 \%$ dengan sifat pertumbuhan allometrik negatif dan korelasi antar panjang dan berat ikan tempakul betina sebesar $56.3 \%$.

Sarwono, 2006 standar pengelompokkan angka korelasi 0 yang artinya tidak ada korelasi antara dua variabel, sedangkan angka korelasi> 0,-0,25 yang artinya korelasi sangat lemah, sedangkan angka korelasi > 0,25-0,5 yang artinya korelasi cukup, angka korelasi > 0,5-0,75 yang artinya korelasi kuat, angka korelasi > 0,75-0,99 yang artinya korelasi sangat kuat dan angka korelasi 1 yang artinya korelasi sempurna.
Nilai korelasi pada tahun 2016 nilai ikan jantan 98,4 \% dan betina 98,9 \% dikatakan memiliki nilai korelasi yang sangat kuat, sedangkan nilai korelasi pada tahun 2018 nilai ikan jantan 98,8 \% memiliki nilai korelasi sangat kuat dan pada ikan betina $79,8 \%$ nilai korelasi kuat dan nilai korelasi pada tahun 2019 nilai ikan jantan $87,4 \%$ memiliki nilai korelasi sangat kuat dan pada betina 56,3\% nilai korelasi kuat. Pada (Tabel 4) persamaan regresi ikan tempakul jantan dan betina yang di perpleh pada tahun 2016 dan 2018 setelah itu dilanjutkan lagi pada tahun 2019 dengan judul yang berbeda tetapi membahas tentang pertumbuhan ikan tempakul.

\section{KESIMPULAN DAN SARAN}

\section{Kesimpulan}

Berdasarkan hasil penelitian yang dilakukan didaerah KKMB disimpulkan bahwa hubungan panjang berat ikan tempakul jantan dan betina bersifat allometrik negatif yang bermakna pertumbuhan panjang lebih cepat dibandingkan perubahan bobot. Berdasarkan persentase faktor kondisi (FK) ikan jantan dan ikan betina yang menunjukkan bahwa tubuh ikan tersebut sangat kurus/pipih. 


\section{Saran}

Untuk penelitian berikutnya perlu adanya penelitian lanjutan mengenai reproduksi dari ikan tempakul yang didapatkan di daerah KKMB Kota Tarakan

\section{UCAPAN TERIMA KASIH}

Ucapan Terimakasih diberikan kepada Heriyana yang telah mendedikasikan hasil penelitian skripsi untuk dapat di publikasikan dalam Jurnal Harpodon Borneo Tahun 2019 dengan Judul Skripsi Hubungan Panjang Berat dan Faktor Kondisi Ikan Tempakul (Periopthalmus barbarous) Di Kawasan Konservasi Mangrove dan Bekantan (KKMB) Kota Tarakan.

\section{DAFTAR PUSTAKA}

A.F.J. Jamsari, Z.A. Muchlisi, M. Musman and M.N. Siti-Azizah, 2010, Remarkably low genetic variation but high population differentiation in the climbing perch, Anabas testudineus (Anabantidae), based on the $m t D N A$ control region, Genetic and Molecular Research, 9(3), 18361843, 16765680.

Djumanto dan N. Probosunu. 2011. Biodiversitas sumber daya ikan di hulu Sungai Opak. Jurnal Iktiologi Indonesia, 11(1):1-10.

Djumanto dan Setyawan, F. 2009. Jurnal Perikanan: Food Habits of the Yellow Rasbora, Rasbora lateristriata, (Family: Broodfish) Broodfish During Moving to Spawning Ground XI (1): 107-114

Effendie, M. I. 1997. Biologi perikanan. Yayasan Pustaka Nusantara, Yogyakarta.

Effendie, M.I., 2002. Biologi Perikanan. Yayasan Pustaka Nusantara, Yogyakarta. faktor kondisi ikan tetet, Johnius belangerii Cuvier Pisces: Sciaenidae di perairan
Pantai Mayangan, Jawa Barat. J. Ilmu-ilmu Perairan dan Perikanan Indonesia, 15(2):135-140.

Effendie, M.L. \& D.S. Sjafei. 1973. Beberapa Aspek Biologi Ikan Glodok (Boleophthalmus boddarti Pallas) dari Daerah Tangerang. Skripsi. Fakultas Perikanan. Institut Pertanian Bogor. Hal. 15

Ibrahim A, Saleh R, Hasrian (1871) Aspek Kebiasaan Makanan Ikan Kurisi Bali (Pristipmoides multidens) yang tertangkap di Perairan Derawan dan sekitarnya. Borneo University Library (1): 1-6

Jonathan, Sarwono. 2006. Metode Penelitian Kuantitatif dan Kualitatif. Yogyakarta: Graha Ilmu.

Kusuma, C. 1995. Ekologi Mangrove. Fakultas Kehutanan Institut Pertanian Bogor. 63 hal

Lagler, K. F.John E. B., Robert E.M. 1962. Ichthyology. John Wiley and Sons Inc. USA. pp:221-225.

Lizama, M., A.P. De Los, and A.M. Ambrosio. 2002. Condition factor in nine species of fish of the characidae family in the Upper Parania River Floodplain, Brazil. J. Biol., 62(1): 113- 124.

Masriwaty, 2002. Hubungan panjang bobot, faktor kondisi dan kebiasaan makan ikan biji nangka (Parupeneus hepthacantus) di Sekitar Perairan Pulau Kodingareng Kecamatan Ujung Tanah Kota Makassar. Skripsi, Jurusan Perikanan. Universitas Hasanuddin, Makassar

Ramadhani, R., 2014. 40 resep jus buah popular. Jakarta: PT. Kawan Pustaka. 
Salim, G. 2013. Nilai indeks kondisi dari ikan siganus javus berdasarkan hasil tangkapan nelayan di Perairan Juata Kota Tarakan. Jurnal Harpodon Borneo Volume 6 Nomor 1. Tahun 2013.

Subadra. (2008). Welcome to Bali. Akademi Pariwisata Triatma JayaDalung. Diakses 20 Desember 2012 dari http//Bali Tourism Watch Ekowisata sebagai Wahana Pelestarian Alam « Welcome to Bali Tourism Watch.htm.].

Tzikas Z, Ambrosiadis I, Soultos N, Georgakis S. 2007. Seasonal size dristribution, condition status and muscle yiel of mediterranean horse mackerel Trachurus Mediterraneus from fhe North Aegean Sea, Greece. Fisheries Science 73: 453462.

Walpole, R. E. 1992. Pengantar Statistika. PT. Gramedia Pustaka Utama, Jakarta.

Yusuf, K. (2008). Sejarah dan pesona alam, kawasan Konservasi Mangrove Bekantan, Tarakan Kalimantan Timur. Tarakan: Pemerintah Daerah Kota Tarakan.

Zuliani Zuliani, Zainal A. Muchlisin, Nurfadillah Nurfadillah, 2016, Kebiasaan makan dan hubungan panjang berat ikan julung-julung (Dermogenys sp.) DI sungai alur hitam kecamatan bendahara Kabupaten Aceh Tamiang, JIM FKP, 1, 12-24, 00000 . 